\title{
Production of Angiotensin-I-Converting Enzyme inhibitory peptide from goat milk casein: optimization conditions of complex protease hydrolysate by response surface methodology and purification
}

\author{
Li Chen ${ }^{1 *}$, Juan Wang ${ }^{2}$, Guowei Shu ${ }^{2 *}$, He Chen ${ }^{2}$ \\ ${ }^{1}$ College of Food Engineering and Nutritional Science, Shaanxi Normal University, Xi'an, China, ${ }^{2}$ School of Food and Biological Engineering, \\ Shaanxi University of Science and Technology, Xi'an, China
}

\section{A B S T R A C T}

\begin{abstract}
Food-derived Angiotensin-I-Converting Enzyme (ACE)-inhibitory peptides have safety advantages over synthetic peptides. The application of complex enzymatic (alcalase and trypsin) in producing such peptides from goat milk casein seldom be focused. In this study, the $\mathrm{pH}$, complex protease ratio (CPR) and enzyme to substrate ratio (E/S) were optimized by Response surface methodology (RSM). The optimized conditions were: $\mathrm{pH} 8.4$, CPR 1:1, and E/S $8.5 \%$. In these conditions, the ACE-inhibitory activity of the obtained hydrolysates reached $91.99 \%$. The response model was qualified to predict the reaction optimization. Hydrolysate fragments were purified consecutively. A fraction $\mathrm{G}_{2-2 \mathrm{a}}$ exhibited highest $A C E$-inhibitory activity $93.50 \%$ with $\mathrm{IC}_{50}$ value of $72.14 \mu \mathrm{g} / \mathrm{mL}$.
\end{abstract}

Keywords: Angiotensin-I-converting enzyme (ACE); Goat casein; Complex protease; Response surface methodology (RSM); Purification

\section{INTRODUCTION}

Hypertension which leads to serious medical and lifestylerelated problem has become a worldwide cardiovascular disease. The peptides which capable of controlling blood pressure are identified as a strong inhibitor of angiotensinI-converting enzyme (ACE, peptidyldipeptide hydrolase, E.C. 3.4.15.1). This inhibitor acts in the rennin-angiotensin system transforming angiotensin I type into II type, then deactivates the depressor bradykinin to lose catalytic function (He et al., 2004; Kong et al., 2011). Therefore, the application of ACE-inhibitory peptides in clinical treatment and function food process is becoming popular globally.

Since the first discovery of ACE-inhibitor from snake (Bothorps jararaca) venom, plenty of approaches have been achieved to obtain ACE-inhibitory peptides from various protein hydrolysates such as cheese whey (Abubakar et al., 1998; Gómez-Ruiz et al., 2002; Guo et al., 2009; Pan et al., 2012), casein (Miguel et al., 2008), zein, walnut (Wang et al., 2014), soy sauce, corn gluten (Ma et al., 2006; Parris et al., 2008), and bovine blood plasma (Hyun and Shin, 2000; Janitha et al., 2002). Additionally, some peptides with ACE-inhibitor activity are isolated from marine animals, such as sardine, tuna, bonito, jellyfish, and sea cucumber (He et al., 2006; Je et al., 2005; Matsumura et al., 1993; Kohama et al., 1988; Matsui et al., 1993; Zhuang et al., 2012; Zhuang et al., 2009; Zhao et al., 2007). With the development of the biotechnology, the enzymatic hydrolysis, ultrafiltration, macroporous resin, and gel chromatography have been successfully combined in the purification of protein hydrolysates (Vercruysse et al., 2008; Saiga et al., 2008; Byun and Kim, 2001; Li et al., 2006; Megías et al., 2004). Furthermore, employment of amino acid sequence encourage us characterize the relationship between peptides activity and structure better.

Goat is the most important cultured farm animal in Shaanxi, China. The production and consumption of goat milk and dairy products are increasing all over the world. The goat milk protein have advantage in digestive ability over

\footnotetext{
${ }^{*}$ Corresponding authors:

Li Chen, College of Food Engineering and Nutritional Science, Shaanxi Normal University, Xi'an, China. E-mail: chenlisp@snnu.edu.cn, Guowei Shu, School of Food and Biological Engineering, Shaanxi University of Science and Technology, Xi'an, China.

E-mail: shuguowei@gmail.com
} 
bovine milk protein, and it seldom bring harmful effects to human being (Montalbano et al., 2016; Lee et al., 2005; Jiang et al., 2007). The most abundant proteins in goat milk are caseins. Previous researches have used single enzyme to hydrolyze milk protein, but the application of combined enzymes to hydrolysis is scarce (Espejo-Carpio et al., 2013; Miguel et al., 2008, Minervini et al., 2003). Response surface methodology (RSM) has advantage to classical one-variablea-time optimization, and therefore is largely applied to optimize the analytical procedures. The experimental design should fit an adequate mathematical function and could evaluate the quality of the fitted model (Kalil et al., 2000). The Box-Behnken design (B-B design) is more efficient and economical to build the response surface mode.

The objective of this study was to optimize the complex enzymatic hydrolysis condition for ACE-inhibitory peptides from goat milk casein by RSMwith the aid of B-B design and Plackett-Burman Design (P-B). The P-B investigates a number of independent variables and determines which variables affect the performance greatly.

\section{MATERIALS AND METHODS}

\section{Enzymes and chemical reagents}

Chemical and enzymes used in our research are shown as follows: ACE, peptide substrate Hip-His-Leu, a peptide substrate Gly-Gly-Tyr-Arg, papain (3.0 U/mg), protease $\mathrm{K}(30 \mathrm{U} / \mathrm{mg})$, trypsin $(250 \mathrm{NFU} / \mathrm{mg})$, alcalase $(2.4 \mathrm{AU} / \mathrm{g})$, neutrase (200000 U/g), SP-Sephadex G-25 and Sephadex G-15 were purchased from Sigma Chemical (St. Louis, MO, USA). All other reagents were analytical grade.

\section{Enzymatic hydrolysis}

Goat' casein was prepared by our lab. Hydrolysis of casein was measured as the method of Adamson and Reynolds (1996). Casein was hydrolyzed under the substrate concentration of $5 \%$ and $\mathrm{E} / \mathrm{S}$ of $5 \%$. The $\mathrm{pH}$ value of the hydrolysis mixture was adjusted with addition of $0.1 \mathrm{~mol} / \mathrm{L}$ $\mathrm{NaOH}$ by pH-Stat (Metrohm Ltd., Herisan, Switzerland). During the reaction, samples were removed after 30, 60, $90,120,150,180,210,240,270,300,330$, and $360 \mathrm{~min}$, and the reaction was ended by heating at $90{ }^{\circ} \mathrm{C}$ for $15 \mathrm{~min}$. The reaction mixture were adjusted to $\mathrm{pH} 3.5$, centrifuged for $15 \mathrm{~min}$ at the speed of $5000 \mathrm{rpm}$, then collected under pH 8.3 for ACE-inhibitory activity determination.

\section{Determination of ACE-inhibitory activity}

The ACE-inhibitory activity was calculated according to the method of Cushman and Cheung (1971). A sample solution $(100 \mu \mathrm{L})$ was incubated with $200 \mu \mathrm{L}$ substrate (5 mM hippuryl-L-histidyl-L-leucine (HHL) dissolved in $0.1 \mathrm{M}$ Na-borate buffer $(0.3 \mathrm{M} \mathrm{NaCl}, \mathrm{pH} 8.3)$ at $37{ }^{\circ} \mathrm{C}$ for $5 \mathrm{~min}$. The reaction system started with $20 \mu \mathrm{L}$ of the ACE solution $(100 \mathrm{mU} / \mathrm{mL})$ at $37^{\circ} \mathrm{C}$ for $30 \mathrm{~min}$ and was terminated by adding $0.25 \mathrm{~mL}$ of $1 \mathrm{M} \mathrm{HCl}$. The hippurylic acid was extracted with the addition of ethyl acetate. After strong vortex, separate $5 \mathrm{~min}$ and $30 \mathrm{~min}$ at $120^{\circ} \mathrm{C}$ in a vacuum. The residue was dissolved in $3 \mathrm{~mL}$ of distilled water. The absorbance was determined at $228 \mathrm{~nm}$ using a spectrophotometer UV5300-PC (Yuanxi, Shanghai, China).

The ACE inhibition was obtained as following (Eq. 1):

Inhibition $=\frac{A-B}{A-C} \times 100 \%$

Which $A$ represented the absorbance of ACE, $B$ represented absorbance with sample and ACE, and $C$ represented the absorbance of sample.

The ACE inhibition meant $50 \%$ of the original ACE activity $\left(\mathrm{IC}_{50}\right)$ was inhibited at a certain protein concentration. The degree of hydrolysis $(\mathrm{DH})$ and protein concentrations were determined according to the methods of $\mathrm{pH}$-Stat and the method of Lowry et al., respectively (1951). Bovine serum albumin was used as the standard in the experiment.

\section{P-B design}

The P-B was used during hydrolysis. In this study, temperature $\left(X_{1}\right), \mathrm{pH}\left(X_{2}\right), E / S\left(X_{3}\right)$, Goat's casein $\left(X_{5}\right)$, complex protease ratio $(\mathrm{CPR}, \mathrm{v} / \mathrm{w})\left(X_{0}\right)$, time $\left(X_{7}\right)$, and two virtual factors $\left(X_{4}\right.$ and $X_{8}$ ) were independent variables (Table 1).

\section{B-B design}

A B-B design among $\mathrm{pH}\left(X_{1}\right), \mathrm{E} / \mathrm{S}\left(X_{2}\right)$, and $\mathrm{CPR}\left(X_{3}\right)$ was arranged as $\mathrm{pH}(8.2,8.4$, and 8.6$), \mathrm{E} / \mathrm{S}(8.0 \%, 8.5 \%$, and $9 \%$ ), and CPR (6:7, 7:7, and 8:7) (Table 2). The calculation exhibited as the follows (Eq. 2).

$\mathrm{Y}=\beta_{0}+\beta_{1} X_{1}+\beta_{2} X_{2}+\beta_{3} X_{3}+\beta_{11} X_{1}^{2}+\beta_{12} X_{1} X_{2}+\beta_{13} X_{1} X_{3}$ $+\beta_{22} X_{2}^{2}+\beta_{23} X_{2} X_{3}+\beta_{33} X^{2}$

\section{Separation of ACE-inhibitory peptides}

Goat casein hydrolysates were separated by an ultrafiltration membrane. Three fractions under $10 \mathrm{kDa}, 5 \mathrm{kDa}$, and $1 \mathrm{kDa}$ were obtained (Millipore, Billerica, USA).

Table 1: P-B design of independent variable

\begin{tabular}{llc}
\hline Factors & Variables & $\begin{array}{c}\text { Coded } \\
\text { Levelsa }\end{array}$ \\
\cline { 3 - 3 } & & $\mathbf{- 1 + 1}$ \\
\hline$X_{1}\left({ }^{\circ} \mathrm{C}\right)$ & Temperature & 4556 \\
$X_{2}$ & $\mathrm{pH}$ & 8.811 \\
$X_{3}(\% \mathrm{w} / \mathrm{w})$ & Enz/subs reation $(E / S)$ & 67.5 \\
$X_{5}(\mathrm{~g} / 100 \mathrm{~mL})$ & Goat'casein & 1215 \\
$X_{6}(\mathrm{v} / \mathrm{w})$ & Complex protease ration & $1: 35: 7$ \\
$X_{7}(\mathrm{~min})$ & Time & 90120 \\
\hline
\end{tabular}


Macroporous resin DA201-C was used to separate fraction $\mathrm{U}_{3}$ under $\mathrm{pH} 4.0$ with $75 \%$ ethanol as eluent. Sephadex G-25 $(1.0 \times 10 \mathrm{~cm})$ and Sephadex G-15 $(1.0 \times 10 \mathrm{~cm})$ were used for further purification at a concentration of $150 \mathrm{mg} / \mathrm{mL}$ with the flow rate of $0.8 \mathrm{~mL} / \mathrm{min}$. RP-HPLC (DiamonsilTMC 18 column $4.6 \times 250 \mathrm{~mm}$ ) with solvent A (acetonitrile) and solvent B [0.1\% trifluoroacetic acid (TFA) in $\mathrm{H}_{2} \mathrm{O}$ ] were prepared for final purification (Waters 600, USA).

\section{Statistical evaluation}

Statistical analysis system SAS9.1 (SAS Institute INC, USA) was used for statistical evaluation. All results were expressed as the means $\pm \mathrm{SD}$ and repeated for three times.

\section{RESULTS AND DISCUSSION}

\section{Screening the complex protease on goat casein hydrolysates}

Enzymatic hydrolysis has been widely used in the production of ACE-inhibitory peptides. It has a clear advantage in less protein destruction, easy controlling, and specific location hydrolysis. The process is consisting of substrate, specific enzyme and the reaction conditions. The enzymes with high frequency in hydrolysis are alcalase, pepsin, neutral protease and trypsin. Alcalase has been used for the generation of ACE-inhibitory peptides from sardine muscle, alaska pollack, jellyfish collagen (Matsui et al., 1993; Zhuang et al., 2012; Byun and Kim, 2001). Jiang et al. (2007) reported that As1398 neutral protease contributed greatly in bovine casein hydrolysis for production of ACE-inhibitory peptides. Pepsin was the best enzyme for the separation of ACE-inhibitory peptides from goat's casein (Lee et al., 2005; Bai et al., 2014). Success of single enzymatic hydrolysis in production of ACEinhibitory peptides has been reported, but the application of complex protease enzymatic hydrolysis in goat casein is scarce.

Table 2: The B-B design for the hydrolysis

\begin{tabular}{lcccc}
\hline Run & $\begin{array}{c}\mathrm{pH} \\
\boldsymbol{X}_{1}\end{array}$ & $\begin{array}{c}\mathrm{E} / \mathrm{S}(\% \boldsymbol{w} / \boldsymbol{w}) \\
\boldsymbol{X}_{2}\end{array}$ & $\begin{array}{c}\text { CPR( } / w) \\
\boldsymbol{X}_{3}\end{array}$ & $\begin{array}{c}\text { ACE } \\
\text { inhibitory }(\%) \boldsymbol{Y}\end{array}$ \\
\hline 1 & 8.2 & 8.0 & $7: 7$ & 72.73 \\
2 & 8.2 & 9.0 & $7: 7$ & 56.36 \\
3 & 8.6 & 8.0 & $7: 7$ & 87.27 \\
4 & 8.6 & 9.0 & $7: 7$ & 38.18 \\
5 & 8.4 & 8.0 & $6: 7$ & 34.55 \\
6 & 8.4 & 8.0 & $8: 7$ & 50.91 \\
7 & 8.4 & 9.0 & $6: 7$ & 29.09 \\
8 & 8.4 & 9.0 & $8: 7$ & 32.73 \\
9 & 8.2 & 8.5 & $6: 7$ & 23.64 \\
10 & 8.6 & 8.5 & $6: 7$ & 25.45 \\
11 & 8.2 & 8.5 & $8: 7$ & 34.55 \\
12 & 8.6 & 8.5 & $8: 7$ & 52.73 \\
13 & 8.4 & 8.5 & $7: 7$ & 87.27 \\
14 & 8.4 & 8.5 & $7: 7$ & 87.22 \\
15 & 8.4 & 8.5 & $7: 7$ & 94.55 \\
\hline
\end{tabular}

In order to find the favorable complex protease, we chose five commercial food grade proteases to digest the goat's casein (Table 3). Each enzymatic hydrolysis was carried out under their suggested optimal conditions during $6 \mathrm{~h}$ (Wang et al., 2010). The best ACE-inhibitory activity of each protease was listed in Table 3. The ACE-inhibitory activity values varied greatly from $74.56 \%$ to $90.00 \%$, and top two were in alcalase and trypsin hydrolytic group $(90.00 \%$ and $87.11 \%)$, respectively. It is consistent with previous researches that alcalase contributes greatly to produce ACE-inhibitory peptides (Adamson and Reynolds, 1996; Kim et al., 2001; Lee et al., 2005; Byun and Kim, 2001). Zhang et al. (2013) reported that the combined and sequential use of alcalase followed by trypsin provided high DH which was much superior to either of them. The peptides derived from goat milk protein showed higher ACE-inhibitory activity when hydrolysed by the combination of ubtilisin and trypsin in comparison to the individual enzyme (Espejo-Carpio et al., 2013).

Trypsin has been widely used to produce ACE-inhibitory peptides from milk protein. Subtilisin, also known as alcalase has low specificity and preferentially cleaves at the C-terminal of hydrophobic residues. We compared five commercial proteases with the consideration of ACEinhibitory activity and fund-saving. Finally, we chose the combination of alcalase and trypsin to hydrolyze goat casein because of their great contribution to ACE-inhibitory activity. Protease $\mathrm{K}$ was abandoned due to high price, although it exhibited great ACE-inhibitory activity (86.67\%).

\section{Minimize the number of variables by $\mathrm{P}-\mathrm{B}$ design}

P-B design was adopted to minimize the number of independent variables through a limited number of experiments. In this study, temperature $\left(X_{1}\right), \mathrm{pH}\left(X_{2}\right), E / S$ $\left(X_{3}\right)$, Goat's casein $\left(X_{5}\right)$, complex protease ratio $(\mathrm{CPR}, \mathrm{v} / \mathrm{w})$ $\left(X_{6}\right)$, time $\left(X_{7}\right)$, and two virtual factors $\left(X_{4}\right.$ and $\left.X_{8}\right)$ were analyzed. Response $(Y)$ represented the ACE-inhibitory activity covered from 65.45 to $92.73 \%$ (Table 4). Low values of the $Y$ were obtained when the group consists of low E/S $\left(X_{3}\right)$, low CPR $\left(X_{6}\right)$ and/ or high $\mathrm{pH}\left(X_{2}\right)$. These results indicated that the $C P R$ and $E / S$ had positive effect while the $\mathrm{pH}$ had negative effect.

Table 3: Comparison of five proteases

\begin{tabular}{lcc}
\hline Proteases & $\begin{array}{c}\text { hydrolysis } \\
\text { conditions }\end{array}$ & $\begin{array}{c}\text { ACE-inhibitory } \\
\text { activity (\%) }\end{array}$ \\
Blank & - & $\mathbf{0}$ \\
\hline Papain & $\mathrm{pH} 5.7,60^{\circ} \mathrm{C}$ & $81.67 \pm 2.67$ \\
Protease $\mathrm{K}$ & $\mathrm{pH} 8,60^{\circ} \mathrm{C}$ & $86.67 \pm 2.58$ \\
Trypsin & $\mathrm{pH} 8,37^{\circ} \mathrm{C}$ & $87.11 \pm 2.51$ \\
Alcalase & $\mathrm{pH} 7.5,55^{\circ} \mathrm{C}$ & $90.00 \pm 2.00$ \\
Neutrase & $\mathrm{pH} 7.0,50^{\circ} \mathrm{C}$ & $74.56 \pm 2.36$ \\
\hline
\end{tabular}

The hydrolysis is consisting of $5 \mathrm{mg} / \mathrm{mL}$ of substrate concentration, $5 \%$ of $\mathrm{E} / \mathrm{S}$ and $6 \mathrm{~h}$ of reaction time. All experiments were repeated in triplicate. Data shown as mean $\pm \mathrm{SD}$ 
Table 4: The P-B design for the hydrolysis

\begin{tabular}{|c|c|c|c|c|c|c|c|c|c|}
\hline Run & $\begin{array}{c}\text { Temperature } \\
x_{1} \\
\end{array}$ & $\begin{array}{l}\mathrm{pH} \\
X_{2} \\
\end{array}$ & $\begin{array}{c}E / S(\% w / w) \\
X_{3} \\
\end{array}$ & $\begin{array}{c}\text { virtual } \\
X_{4}\end{array}$ & $\begin{array}{c}\text { Goat's } \\
\text { casein }(\mathrm{g} / 100 \mathrm{~mL}) X_{5}\end{array}$ & $\begin{array}{l}\text { complex protease } \\
\text { ratio }(\mathrm{v} / \mathrm{w}) X_{6}\end{array}$ & $\begin{array}{c}\text { Time (min) } \\
x_{7}\end{array}$ & $\begin{array}{c}\text { virtual } \\
X_{8}\end{array}$ & $\begin{array}{c}\text { ACE inhibitory (\%) } \\
Y\end{array}$ \\
\hline 1 & 56 & 8.8 & 7.5 & 0 & 12 & $1: 3$ & 90 & 0 & 74.55 \\
\hline 2 & 56 & 11 & 6 & 0 & 12 & $1: 3$ & 90 & 0 & 69.09 \\
\hline 3 & 45 & 11 & 7.5 & 0 & 15 & $1: 3$ & 120 & 0 & 72.73 \\
\hline 4 & 56 & 8.8 & 7.5 & 0 & 12 & $5: 7$ & 90 & 0 & 87.27 \\
\hline 5 & 56 & 11 & 6 & 0 & 15 & $1: 3$ & 120 & 0 & 67.27 \\
\hline 6 & 56 & 11 & 7.5 & 0 & 15 & $5: 7$ & 120 & 0 & 76.36 \\
\hline 7 & 45 & 11 & 7.5 & 0 & 12 & $5: 7$ & 90 & 0 & 92.73 \\
\hline 8 & 45 & 8.8 & 7.5 & 0 & 15 & $1: 3$ & 120 & 0 & 78.18 \\
\hline 9 & 45 & 8.8 & 6 & 0 & 15 & $5: 7$ & 120 & 0 & 85.45 \\
\hline 10 & 56 & 8.8 & 6 & 0 & 15 & $5: 7$ & 120 & 0 & 83.64 \\
\hline 11 & 45 & 11 & 6 & 0 & 12 & $5: 7$ & 90 & 0 & 70.91 \\
\hline 12 & 45 & 8.8 & 6 & 0 & 12 & $1: 3$ & 90 & 0 & 65.45 \\
\hline
\end{tabular}

To further confirm the variables effect, the trends of response value $Y$ with 8 variables were described in Fig. 1. When the four factors $\left(X_{3}\right),\left(X_{4}\right),\left(X_{6}\right),\left(X_{7}\right)$ increased, the response value $Y$ kept rising following. However, on the contrary, the response value $Y$ dropped off when the value $\left(X_{1}\right),\left(X_{2}\right)$ and $\left(X_{8}\right)$ increased. Since $\left(X_{8}\right)$ and $\left(X_{4}\right)$ were virtual factors and excluded to the consideration. Three variables $E / S\left(X_{3}\right), \mathrm{CPR}\left(X_{6}\right)$ and $\mathrm{pH}\left(X_{2}\right)$ exhibited strong influences which were similar to the study of Zhuang, which found $E / S$ and $\mathrm{pH}$ play important roles in jellyfish collagen hydrolysis (Zhuang et al., 2012).

\section{The B-B design and RSM analysis}

$\mathrm{B}-\mathrm{B}$ design is the statistical experimental design for the efficient estimation of the second-order coefficients of the mathematical model. Some changes were made for $\mathrm{B}-\mathrm{B}$ experiment based on the $\mathrm{P}-\mathrm{B}$ design results. The value range of $E / S$ and $C P R$ was increased, and the range of $\mathrm{pH}$ decreased. A three-level-three-factor B-B design was carried out to evaluate the hydrolysis condition (Table 2). As shown in Table 5, the significance of variables and their interactions were expressed by $p$-values. $E / S$ had strong effects $(P<0.05)$ but $\mathrm{CPR}$ and $\mathrm{pH}$ not $(P>0.05)$. The terms of $\mathrm{CPR}^{2},(E / S)^{2}$ and $\mathrm{pH}^{2}$ exhibited high significant $(P<0.05)$ and high $F$ value, indicated that variables and response had no simple linear correlation. The term of $\mathrm{pH}$ $\times E / S, \mathrm{pH} \times \mathrm{CPR}$, and $\mathrm{pH} \times \mathrm{CPR}$ showed no significant $(P>0.05)$ and low $F$ value, which demonstrated a weak mutual interaction between them.

Statistical significance of the equation is shown in Table 5 . The $F$ value was 13.3654 which meant this mathematics model highly fitted the prediction of ACE inhibition (\%) $(P<0.01)$. The suitability and validity of the quadratic model was evaluated by coefficient of determination $\left(R^{2}\right)$. The values of $R^{2}$ and adjusted $R^{2}$ of the polynomial model were $96.01 \%$ and $88.83 \%$, respectively. The $R^{2}$ value of 0.9601 indicated that more than $96.01 \%$ of the data fitted the equation (Eq. 3):

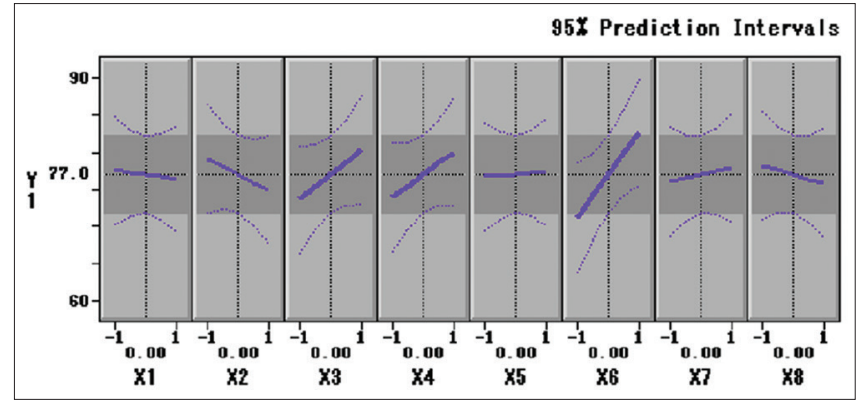

Fig 1. The trends of response value "ACE-inhibitory activity $(Y)$ " with variables.

$\%$ Inhibition $=89.697+2.044 \mathrm{pH}-11.138 \mathrm{E} / \mathrm{S}$

$+7.274 C P R-14.395 \mathrm{pH}^{2}-8.18 \mathrm{p} H \times+4.093 \mathrm{pH} \times C P R$

- 11.667(E/S)-3.18E/S $\times C P R-41.21 C P R^{2}$

The 3D response surface and $2 \mathrm{D}$ contour plots were depicted (Fig. 2). The ellipse obtained in contour plot suggested that $Y$ had enhanced until $X_{1}, X_{2}$, and $X_{3}$ were at the best appropriate condition. The best hydrolysis seemed to be $\mathrm{pH} 8.4$, CPR 7:7, and E/S 8.5\% with $Y$ of $92.35 \%$. A $Y$ value of $91.99 \%$ was obtained under this best hydrolysis condition. The combination of complex protease alcalase and trypsin was successful in hydrolyzing goat casein.

\section{Separation of inhibitory peptides from casein}

Casein hydrolysis were separated into three fractions. The highest ACE-inhibitory activity from fraction $\mathrm{U}_{3}$ was $89.09 \%$ with the $\mathrm{IC}_{50}$ value of $298.34 \pm 10.61 \mu \mathrm{g} / \mathrm{mL}$ (Table 6). A macroporous resin DA201-C and Sephadex G-25 were used for purification. The ACE-inhibitory activity of fraction $\mathrm{G}_{2}$ was $91.23 \%$ and $\mathrm{IC}_{50}$ value was $175.00 \pm 6.71 \mu \mathrm{g} / \mathrm{mL}$ (Fig. 3a). Fraction $\mathrm{G}_{2-2}$ exhibited high ACE-inhibitory activity $(92.16 \%)$ with $\mathrm{IC}_{50}$ value being $134.03 \pm 24.61 \mu \mathrm{g} / \mathrm{mL}$ when purified on $\mathrm{G}-15$ column (Fig. 3b). RP-HPLC was used for final purification under the C18 column (Fig. 3c). A peak was identified as $G_{2-2 a}$ 


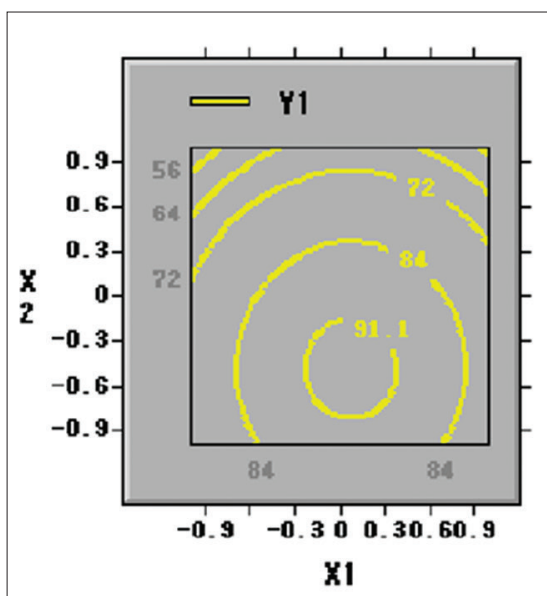

a

Fixed levels: $\quad$ X3 $=0$

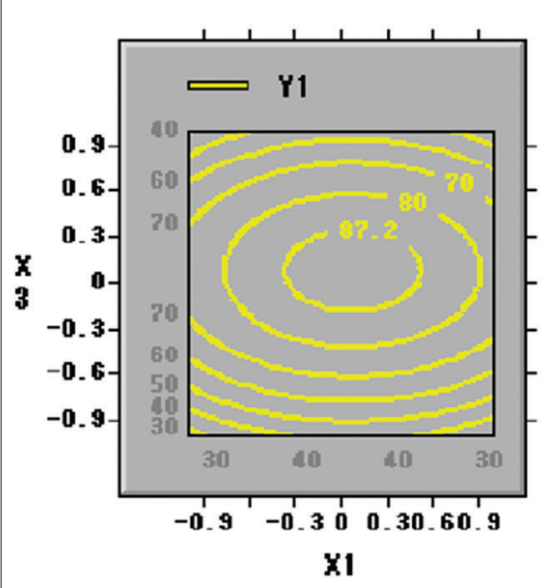

Fixed levels: $\quad \mathrm{X} 2=0$

b

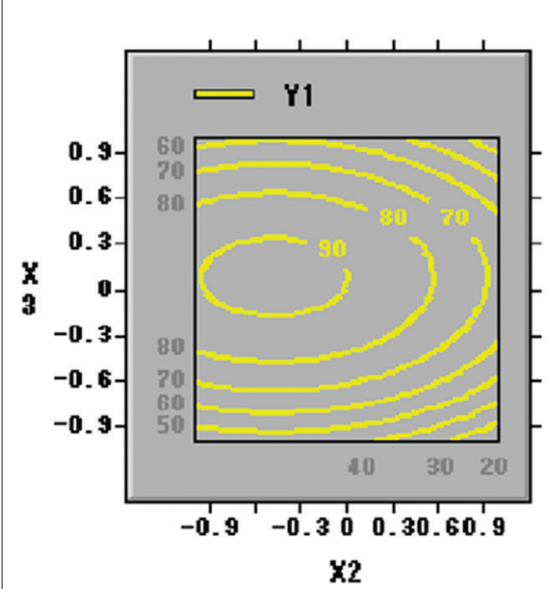

Fixed levels: $\quad \mathbf{X} 1=0$

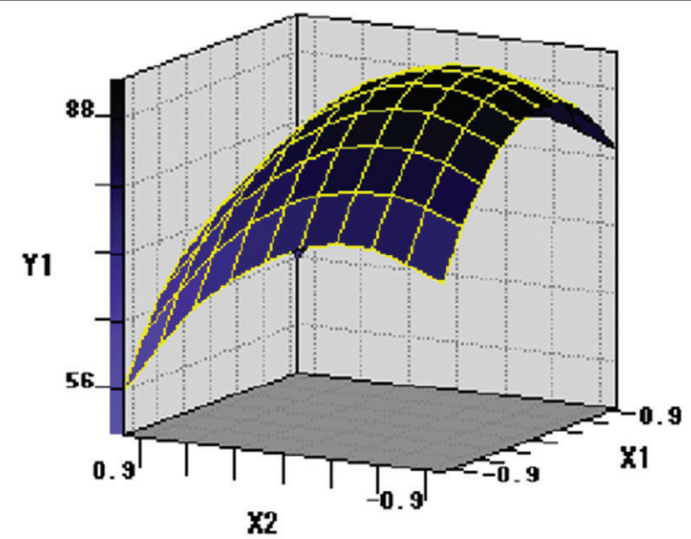

Fixed levels: $\quad$ X3 $=0$

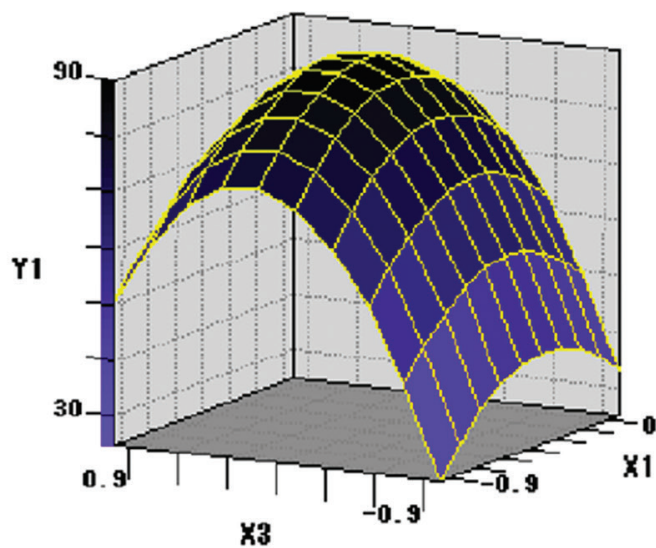

Fixed lerels: $\quad X_{2}=0$

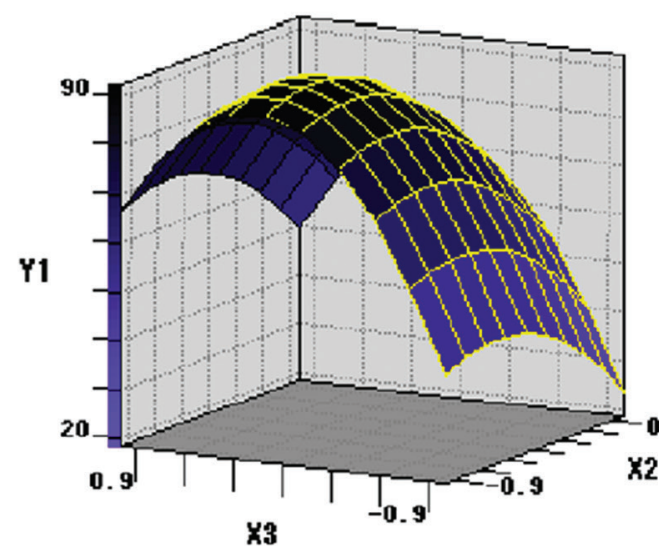

Fixed levels: $\quad X 1=0$

Fig 2. The response surface. (a) pH vs. E/S at the CPR of 7:7, (b) pH vs. CPR at the E/S of $8.5 \%$, (c) E/S vs. CPR at the pH of 8.4 . 


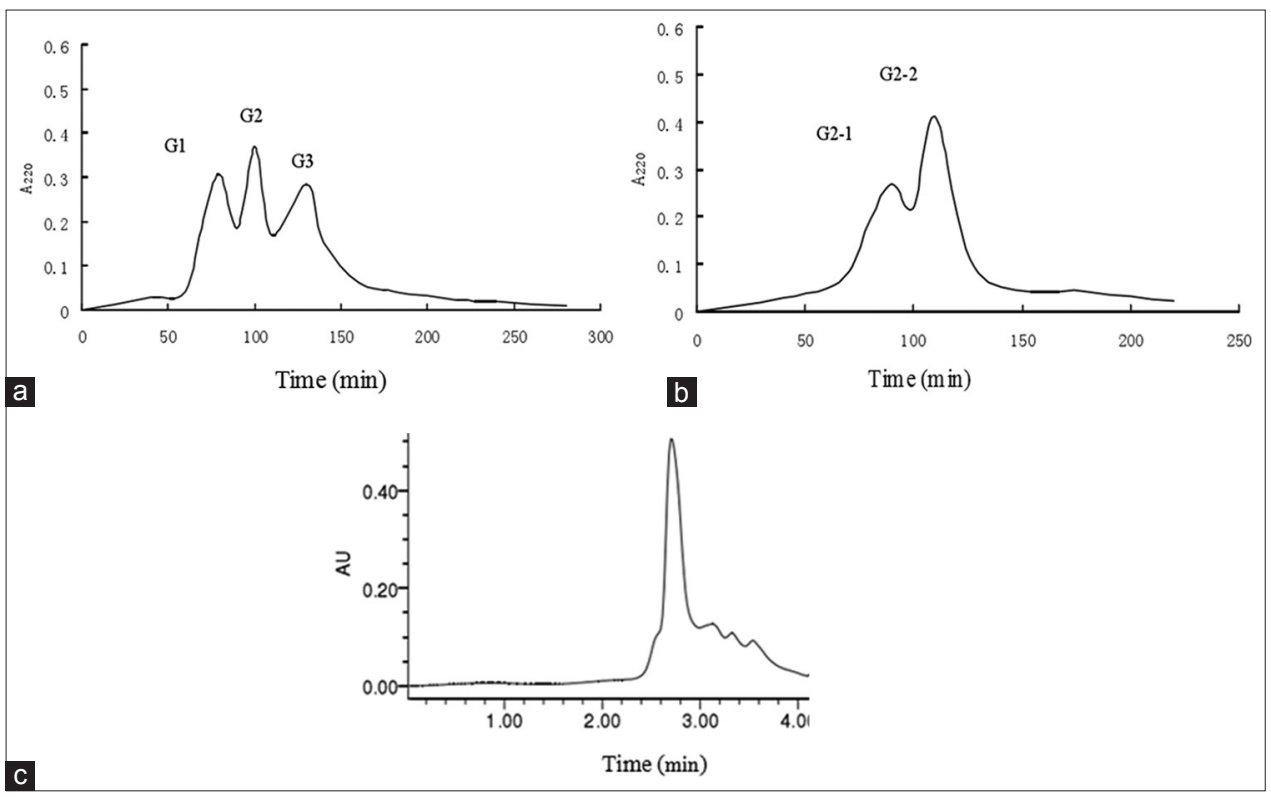

Fig 3. Separation and Purification. (a) Sephadex G-25 chromatogram of U3. (b) Sephadex G-15 chromatogram of $G_{2}$. (c) RP-HPLC of $G_{2-2}$. on a DiamonsilTMC 18 column. Elution was performed with solvent B [0.1\% trifluoroacetic acid (TFA) in H2O] for 10 min.

Table 5: Analysis of variance (ANOVA)

\begin{tabular}{|c|c|c|c|}
\hline \multirow[t]{2}{*}{ Variance } & \multicolumn{2}{|c|}{$\begin{array}{l}\text { ACE-inhibitory } \\
\text { activity }\end{array}$} & \\
\hline & $F$ ration & $P$ value & \\
\hline $\mathrm{pH}$ & 0.4576 & 0.5288 & \\
\hline $\mathrm{E} / \mathrm{S}$ & 13.5900 & $0.0142^{*}$ & \\
\hline CPR (Complex protease ration) & 5.7964 & 0.0610 & \\
\hline $\mathrm{pH}^{2}$ & 10.4773 & $0.0230^{*}$ & \\
\hline $\mathrm{pH} \times \mathrm{E} / \mathrm{S}$ & 3.6654 & 0.1137 & \\
\hline $\mathrm{pH} \times \mathrm{CPR}$ & 0.9175 & 0.3821 & \\
\hline $\mathrm{E} / \mathrm{S}^{2}$ & 6.8830 & $0.0469^{*}$ & \\
\hline $\mathrm{E} / \mathrm{S} \times \mathrm{CPR}$ & 0.5539 & 0.4902 & \\
\hline $\mathrm{CPR}^{2}$ & 85.8715 & $0.0003^{\star *}$ & \\
\hline Linear & 6.6147 & $0.0342^{*}$ & \\
\hline Quadratic & 31.7693 & $0.0011^{* *}$ & \\
\hline Cross-product & 1.7123 & 0.2793 & \\
\hline Model & 13.3654 & $0.0054^{\star *}$ & $0.9601\left(R^{2}\right)$ \\
\hline
\end{tabular}

*indicates significant difference $P<0.05$; **indicates significant difference $P<0.01$

showed high inhibitory activity of $93.50 \%$ with $\mathrm{IC}_{50}$ value being $72.14 \pm 5.52 \mu \mathrm{g} / \mathrm{mL}$ (Table 6).

The composition of amino acids has a close relationship with protein structure which maintains bioactive function (Zhao et al., 2007). So far, the peptides have hydrophobic amino acids on their C-terminal or contained branchedchain aliphatic amino acids exhibited high ACE-inhibitory activity (Wang et al., 2014; Cheung et al., 1980). Maruyama et al. (1985) discovered an ACE-inhibitory peptide with sequence of Ala-Val-Pro-Tyr-Pro-Gln-Arg from bovine milk. Lee et al (2005) found a peptide of Ala-Tyr-PheTyr from goat milk. In our study, the composition of Glu, Ala, Val, Pro, Leu and Asp in purification peptides
Table 6: Purification of $G_{2-2 a}$ from casein enzymatic hydrolysis

\begin{tabular}{llcc}
\hline Fractions & Step & $\mathrm{IC}_{50}(\mu \mathrm{g} / \mathrm{mL})$ & $\begin{array}{c}\text { ACE-inhibitory } \\
\text { activity }(\%)\end{array}$ \\
\hline $\mathrm{U}_{3}$ & Ultrafiltration & $298.34 \pm 10.61$ & 89.09 \\
$\mathrm{U}_{3}$ & DA201-C & $257.01 \pm 13.58$ & 90.12 \\
$\mathrm{G}_{2}$ & Sephadex $\mathrm{G}-25$ & $175.00 \pm 6.71$ & 91.23 \\
$\mathrm{G}_{2-2}$ & Sephadex $\mathrm{G}-15$ & $134.03 \pm 24.61$ & 92.16 \\
$\mathrm{G}_{2-2 a}$ & RP-HPLC & $72.14 \pm 5.52$ & 93.50 \\
\hline
\end{tabular}

remains unclear. We speculate the characteristic amino acid composition is attributed to the local natural and human environment. Taken all the previous information together, peptides separated in our experiment might have different sequence characteristics to those peptides above, but needs more detailed identification.

\section{CONCLUSION}

The use of proteins from various types of milk as a source of anti-hypertensive peptides remains an increasing interest in recent years. In this study, the hydrolysis condition of complex trypsin and alcalase in goat's casein were investigated. In our study, the ACE-inhibitory activity was mainly dependent on the casein $E / S$ and CPR. With the aid of RSM, the optimal conditions were $\mathrm{pH}$ of 8.4 , CPR of $1: 1$, and $E / S$ of $8.5 \%$. The hydrolysate ACEinhibitory peptides exhibited high activity of $91.99 \%$ under the optimum condition. Fragment $G_{2-2 a}$ was purified consecutively. The $\mathrm{IC}_{50}$ value of $\mathrm{G}_{2-2 \mathrm{a}}$ reached the maximum of $72.14 \pm 5.52 \mu \mathrm{g} / \mathrm{mL}$, and the ACE-inhibitory activity was up to $93.50 \%$. The characterization of the amino acid sequence would help us better elucidate the mechanism of 
inhibition. The optimum hydrolysis condition encourages the further industrial production of ACE-inhibitory peptides from goat milk.

\section{ACKNOWLEDGMENT}

This study was financially supported by Shaanxi science and technology research project (2017NY-147) and Fundamental Research Funds (GK201703068).

\section{AUTHORS' CONTRIBUTIONS}

L. C. wrote the article and modified it. J. W. contributed to the experiment. H. C. and G. S. took in charge of the study design.

\section{REFERENCES}

Abubakar, A., T. Saito, H. Kitazawa, Y. Kawai and T. Itoh. 1998. Structural analysis of new antihypertensive peptides derives from cheese whey protein by proteinase K digestion. Dairy Sci. 81: 3131-3138.

Adamson, N. J. and E. C. Reynolds. 1996. Characterization of casein phosphopeptides prepared using alcalase: Determination of enzyme specificity. Enzyme Microb. Technol. 19: 202-207.

Bai, T. H., R. S. Pan, Y. P. Ma, F. J. Xiang and H. J. Ma. 2014. Optimization of enzymatic hydrolysis conditions for casein by response surface methodology. Sci. Tech. Food Ind. 23: 203-206.

Byun, H. G. and S. K. Kim. 2001. Purification and characterization of angiotensin I converting enzyme (ACE) inhibitory peptides from Alaska pollack (Theragra chalcogramma) skin. Process. Biochem. 36: 1155-1162.

Cheung, H. S., F. L. Wang, M. A. Ondetti, E. F. Sabo and D. W. Chushman. 1980. Binding of peptides substrates and inhibitors of ACE. J. biol. Chem. 255: 401-407.

Cushman, D. W. and H. S. Cheung. 1971. Spectrophotometric assay and properties of the angiotensin-converting enzyme of rabbit lung. Biochem. Pharm. 20: 1637-1648.

Espejo-Carpio, F. J., C. De Gobba, A. Guadix, E. M. Guadix and J. Otte. 2013. Angiotensin I-converting enzyme inhibitory activity of enzymatic hydrolysates of goat milk protein fractions. Int. Dairy J. 32(2): 175-183.

Gómez-Ruiz, J. Á., M. Ramos and I. Recio. 2002. Angiotensinconverting enzyme-inhibitory peptides in Manchego cheese manufactured with different starter cultures. Int. Dairy J. 12: 697-706.

Guo, Y. X., D. D. Pan and M. Tanokura. 2009. Optimization of hydrolysis conditions for the production of the angiotensin-I converting enzyme (ACE) inhibitory peptides from whey protein using response surface methodology. Food Chem. 114: 328-333.

He, H., X. Chen, C. Sun, Y. Zhang and B. Zhou. 2006. Analysis of novel angiotensin-I-converting enzyme inhibitory peptides from protease-hydrolyzed marine shrimp acetes chinensis. J. Peptide Sci. 12: 726-733.

He, H., X. Chen, C. Sun and Y. Zhang. 2004. Research progress in inhibitory peptides of angiotensin converting enzyme. China Biotechnol. 24: 7-11.

Hyun, C. K. and H. K. Shin. 2000. Utilization of bovine blood plasma proteins for the production of angiotensin-I-converting enzyme inhibitory peptides. Process Biochem. 36: 65-71.

Janitha, P. K., P. D. Wanasundara, A. R. S. Ross, R, Amarowicz, S. J. Ambrose, R. B. Pegg and P. J. Shand. 2002. Peptides with angiotensin l-converting enzyme (ACE) inhibitory activity from defibrinated, hydrolyzed bovine plasma. J. Agric. Food Chem. 50: 6981-6988.

Jiang, J., S, Chen, F, Ren, Z, Luo and S. S. Zeng. 2007. Yak milk casein as a functional ingredient: Preparation and identification of angiotensin-l-converting enzyme inhibitory peptides. J. Dairy Res. 74: 18-25.

Kalil, S. J., F. Maugeri and M. I. Rodrigues. 2000. Response surface analysis and simulation as a tool for bioprocess design and optimization. Process Biochem. 35: 539-550.

Kim, S. K., H. G. Byun, P. J. Park and F. Shahidi. 2001. Angiotensin I converting enzyme inhibitory peptides purified from bovine skin gelatin hydrolysate. J. Agric. Food Chem. 49: 2992-2997.

Kong, Q., F. Chen, X. Wang, J. Li, B. Guan and X. Lou. 2011. Optimization of conditions for enzymatic production of ACE inhibitory peptides from collagen. Food Bioprocess. Technol. 4: 1205-1211.

Kohama, Y., S. Matsumoto, H. Oka, T. Teramoto, M. Okabe and T. Mimura. 1998. Isolation of angiotensin-converting enzyme inhibitory from tuna muscle. Biochem. Bioph. Res. Co. 155: 332-337.

Lee, K. J., S. B. Kim, J. S. Ryu, H. S. Shin and J. W. Lim. 2005. Separation and purification of angiotensin converting enzyme inhibitory peptides derived from goat's milk casein hydrolysates. Asian-Austral. J. Anim. 18: 741-746.

Li, G. H., J. Z. Wan, G. W. Le and Y. H. Shi. 2006. Novel angiotensin I-converting enzyme inhibitory peptides isolated from alcalase hydrolysate of mung bean protein. J. Peptide Sci. 12: 509-514.

Lowry, O. H., N. J. Rosebrough, A. L. Farr and R. J. Randall. 1951. Protein measurement with the folin phenol reagent. J. Biol. Chem. 193: 265-275.

Ma, M. S., I. Y. Bae, H. G. Lee and C. B. Yang. 2006. Purification and identification of angiotensin-l-converting enzyme inhibitory peptide from buckwheat. Food Chem. 96: 36-42.

Maruyama, S., K. Nakagomi, N. Tomizuka and H. Suzuki. 1985. Angiotensin I-converting enzyme inhibitor derived from an enzymatic hydrolysate of casein. II. Isolation and bradykininpotenting activity on the uterus and the ileum of rats. Agric. Biol. Chem. 49(5): 1405-1409.

Matsumura, N., M. Fujii, Y. Takeda, K. Sugita and T. Shimizu. 1993. Angiotensin-I-converting enzyme inhibitory peptides derived from bonito bowels autolysate. Bio. Biotech. Biochem. 57: 695-697.

Matsui, T., H. Matsufuji, E. Seki, K. Osajima., M. Nakashima and Y. Osajima. 1993. Inhibition of angiotensin-I-converting enzyme by Bacillus licheniformis alkaline protease hydrolyzates derived from sardine muscle. Bio. Biotech. Biochem. 57: 922-925.

Megías, C., M. D. M. Yust, J. Pedroche, H. Lquari, J. Girón-calle, M. Alaiz, F. Millán and J. Vioque. 2004. Purification of an ACE peptide after hydrolysis of sunflower (Helianthus annuus L.) protein isolates. J. Agric. Food Chem. 52: 1928-1932

Miguel, M., M. M. Contreras, I. Recio and A. Aleixandre. 2008. ACE inhibitory and antihypertensive properties of a bovine casein hydrolysate. Food Chem. 112: 211-214.

Minervini, F., F. Algaron, C. G. Rizzello, P. F. Fox, V. Monnet and M. Gobbetti. 2003. Angiotensin I-converting-enzyme-inhibitory and antibacterial peptides from Lactobacillus helveticus PR4 proteinase-hydrolyzed caseins of milk from six species. Appl. Environ. Microb. 69: 5297-5305. 
Montalbano, M., R. Segreto, R. D. Gerlando, S. Mastrangelo and Sardina. 2016. Quantitative determination of casein genetic variants in goat milk: Application in Girgentana dairy goat breed. Food Chem. 192: 760-764.

Pan, D., J. Cao, H. Guo and B. Zhao. 2012. Studies on purification and the molecular mechanism of a novel ACE inhibitory peptide from whey protein hydrolysate. Food Chem. 130: 121-126.

Parris, N., R. A. Moreau, D. B. Johnston, L. C. Dickey and R. E. Aluko. 2008. Angiotensin I converting enzyme-inhibitory peptides from commercial wet- and dry-milled corn germ. J. Agric. Food Chem. 56: $2620-2623$

Saiga, A., K. Iwai and T. Hayakawa. 2008. Angiotensin I-converting enzyme-inhibitory peptides obtained from chicken collagen hydrolysate. J. Agric. Food Chem. 56: 9586-9591.

Vercruysse, L., G. Smagghe, T. Matsui and J. Van Campb. 2008. Purification and identification of an angiotensin I converting enzyme (ACE) inhibitory peptide from the gastrointestinal hydrolysate of the cotton leafworm, Spodoptera littoralis. Process Biochem. 43: 900-904.

Wang, C., W. Song, L. Z. Jiang and M. Du. 2014. Purification and identification of an ACE inhibitory peptide from walnut protein hydrolysate. Eur. Food Res. Technol. 239: 333-338.

Wang, L., X. Mao, X. Cheng, X. Xiong and F. Ren. 2010. Effect of enzyme type and hydrolysis conditions on the in vitro angiotensin I-converting enzyme inhibitory activity and ash content of hydrolysed whey protein isolate. Int. J. Food Sci. Technol. 45: 807-812.

Zhang, G. S., W. Y. Ding, Y. Wang, D. S. Wei and X. X. Yue. 2013. Optimization of casein hydrolyzed by alcalase and trypsin using response surface methodology. Food Sci. 34: 237-241.

Zhao, Y. H., B. F. Li, Z. Y. Liu, S. Y. Dong, X. Zhao and M. Y. Zeng. 2007. Antihypertensive effect and purification of an ACE inhibitory peptide from sea cucumber gelatin hydrolysate. Process Biochem. 42: 1586-1591.

Zhuang, Y. L., L. P. Sun and B. F. Li. 2012. Production of the angiotensin-i- converting enzyme (ACE)- inhibitory peptide from hydrolysates of jellyfish (Rhopilema esculentum) collagen. Food Bioprocess Technol. 5: 1622-1629.

Zhuang, Y. L., X. Zhao and B. F. Li. 2009b. Optimization of antioxidant activity by response surface methodology in hydrolysates of jellyfish (Rhopilema esculentum) umbrella collagen. J. Zhejiang Univ. Sci. B. 10: 572-579. 